\title{
TRADISI TOLAK BALA SEBELUM TANAM PADI PADA MASYARAKAT DESA SIMAROKEN KABUPATEN PASAMAN (KAJIAN LIVING AL-QUR'AN)
}

Rahmat Imanda, ${ }^{1}$ Zulheldi, $^{2}$ Widia Fithri, ${ }^{3}$ Edriagus Saputra ${ }^{4}$

${ }^{1,2,3}$ Universitas Islam Negeri Imam Bonjol Padang, ${ }^{4}$ Institut Agama Islam Sumatera Barat Pariaman J1. Prof. Mahmud Yunus Lubuk Lintah, Kota Padang, Sumatera Barat e-mail: rahmatimandasinaga@gmail.com, zulheldizulheldi@gmail.com, widiafithri71@gmail.com, saputraedriagus@gmail.com

\begin{abstract}
Abstrak: Tradisi tolak bala yang dilakukan oleh masyarakat Desa Simaroken merupakan bentuk penolak musibah yang akan datang pada tanaman yang akan ditanam. Masyarakat setempat meyakini bahwa dengan melakukan tradisi tersebut dapat terhindar dari penyakit terhadap tanamana mereka. Penelitian ini bertujuan untuk mendeskripsikan tradisi tolak bala sebelum menanam padi pada masyarakat desa Simaroken Kabupaten Pasaman. Penelitian ini menggunakan metode kualitatif field research (penelitian lapangan). Untuk mendapatkan data penelitian ini, maka penulis melakukan observasi, wawancara dan dokumentasi dengan responden seperti pihak pemerintahan, ulama, tokoh masyarakat dan masyarakat pada umumnya. Hasil penelitian menunjukkan bahwa masyarakat Simaroken meyakini tradisi tolak bala dapat menjauhkan mereka dan tanamannya dari segala marabahaya. Prosesi tradisi tolak bala sebelum menanam padi dilaksanakan oleh semua masyarakat setempat dengan menyediakan makanan, minuman yang akan dihidangkan pada acara tersebut dan menu utamanya, yaitu lamang sipuluik. Karena lamang yang terbuat dari sipuluik (ketan) merupakan bagian dari yang ditanam oleh masyarakat setempat dan sebagai simbolis dari hasil tanamannya. Tradisi tolak bala dipimpin oleh seorang ulama dengan prosesi awali membaca surat yasin, al-Ikhlas, al-Falaq, al-Naas dan beberapa surat lainnya yang diikuti oleh seluruh masyarakat serta doa yang dipimpin oleh seorang ustad serta diakhiri dengan menyantap hidangan secara bersama-sama.
\end{abstract}

Kata Kunci: Tradisi Tolak Bala, Tanam Padi, Desa Simaroken, Living Qur'an

Abstract: The tradition of rejecting reinforcements carried out by the Simaroken Village community is a form of repellent to future disasters on the plants to be planted. Local people believe that by carrying out this tradition, they can avoid diseases to their plants. This study aims to describe the tradition of rejecting reinforcements before planting rice in the Simaroken village community, Pasaman Regency. This study uses a qualitative field research method (field research). To obtain the data of this study, the authors conducted observations, interviews and documentation with respondents such as the government, ulama, community leaders and the community in general. The findings of this study are that the Simaroken community believes that the tradition of rejecting reinforcements can keep them and their plants away from all harm. The traditional procession of rejecting reinforcements before planting rice is carried out by all local people by providing food, drinks that will be served at the event and the main menu, namely lamang sipuluik. Because the lamang made of sipuluik (sticky rice) is part of what is planted by the local community and as a symbol of the results of the plant. The tradition of rejecting reinforcements is led by a cleric with a procession starting with reading the letter Yasin, al-Ikhlas, al-Falaq, al-Naas and several other letters followed by the whole community and a prayer led by a cleric and ending with eating a meal together .

Keywords: The Tradition of Tolak Bala, rice Planting, Simaroken Village, Living Qur'an 


\section{PENDAHULUAN}

Al-Qur'an merupakan kalamullah yang diturunkan melalui malaikat Jibril kepada Nabi Muhammad SAW. Al-Qur'an memiliki banyak petunjuk dan pedoman serta ilmu bagi umat manusia dalam melaksanakan kehidupan di dunia ini.(Andana 2020). Dalam memahami dan mentadaburi isinya, maka umat Islam sangat membutuhkan ilmu yang terkait, seperti ilmu Tafsir, ilmu hadis, ilmu fiqh, ilmu sosial, ilmu bahasa Arab, ilmu living AlQur'an dan sebagainya. (Saputra and Fata 2021).

Living Al-Qur'an merupakan sebuah keilmuan yang mengkajian terkait dengan pengamalan masyarakat yang memiliki kaitannya dengan syariat Islam. (Saputra 2019a). Karena Al-Qur'an merupakan sumber keilmuan yang selalu menyatu dengan ruang dan waktu dimana Al-Qur'an itu hadir, artinya Al-Qur'an selalu ada bagi manusia dimana dan kapanpun mereka butuhkan, karena salah satu fungsi dari AlQur'an adalah memberi petunjuk. (Aziz et al. 2010) Serta Al-Qur'an bukanlah sesuatu yang harus diantikkan yang harus di pajang di tempat-tempat tertentu, tetapi bagaimana Al-Qur'an itu secara kultur dapat dirasakan secara sosiologis dan dapat dipraktikkan. (Shihab et al. 2015)

Selain dari segi kultur dan sosial, AlQur'an juga berfungsi sebagai alat penyembuh atau disebut dengan ruqyah. Sebagaimana yang telah disebutkan oleh Farid Esack, seorang sarjana muslim yang berasal dari Afrika Selatan, ia menyebutkan dalam sebuah karyanya dalam bentuk tulisan, bahwa Al-Qur'an itu hidup seperti manusia layaknya ia mempunyai jiwa. (Saputra, 2021) Serta jadi sarana untuk mempererat hubungan dengan Allah SWT, salah satu caranya dengan mengetahui arti dari teks Al-Qur'an. (Hasbullah et al., 2017)

Dalam arti lain, Al-Qur'an mempunyai fungsi selain kedudukannya sebagai teks agama, (Hidayat 2019) ini bisa dikatakan sebagai fungsi perpormatis atau ketika Al-Qur'an itu dibaca atau ditulis atau digunakan dan diamalkan untuk tujuan tertentu. Maka dalam keadaan beginilah teks Al-Qur'an tersebut diterima dan dimaknai oleh masyarakat dalam dimensi sosial budaya. (Aisyah, 2016). Dari proses itulah muncul bermacam sikap dan menjadi kebiasaan dalam kehidupan bermasyarakat. (Zulfadli et al. 2021).

Dari berbagai bentuk respon terhadap fungsi Al-Qur'an itu, bermunculanlah tradisi-tradisi masyarakat, dimana Al-Qur'an bisa lebih menyatu dengan semua prilaku masyarakat. (Gusnanda 2020). Salah satunya ialah tradisi tolak bala yang dilakukan oleh masyarakat desa Simaroken, yang penduduk masyarakatnya adalah petani yang hanya mengandalkan alam untuk mendapatkan panen yang memuaskan, baik dari segi perairannya, hama atau penyakit tanaman yang bisa tiba-tiba bisa datang sendiri. Dari pernyataan masyarakat ini menyatakan bahwa, acara tolak bala bukanlah hanya bentuk tradisi yang mengharapkan panen labih baik, tapi sebuah pemahaman masyarakat terhadap fungsi Al-Qur'an (sebagai obat). (Eviyanti, 2018)

Masyarakat desa Simaroken ini dikenal dengan menganut aliran Tarekat 
Naqsyabandiyah, Tarekat (Ath-Thariqah), jamaknya (Taraiq) secara etimologis berarti jalan,cara (Al-Kaifiyyah), metode, sitem (AlUslub), madzhab, aliran, haluan (AlMadzhab), keadaan (Al-Halah), pohon Kurmayang tinggi (An-Naklhah AtThawilah), tiang tempat berteduh, tongkat payung ('Amud AlMizallah), yang mulia, terkemuka dari kaum (Syarif Al-Qaum), goresan, garis pada sesuatu (Al-Khatt Fis Sya'i). Sedangkan menurut istilah Tasawuf, tarekat berarti perjalanan seorang Salik (pengikut tarekat) menuju Tuhan dengan cara menyucikan diri atau perjalanan yang harus ditempuh oleh seseorang untuk dapat mendekatkan diri sedekat mungkin kepada Tuhan. (Al Misri, 1994) Tarekat merupakanperjalan Rohani (Nurani, Jiwa, Hati Rabbani) yang berjalan mencari Allah. Perjalanan yang bertingkat-tingakat, dari satu tingkat demi satu tingkat, hingga ia bertemu dengan Allah. (Masyuhri. 2011)

Dari pemahaman agama dan tarekat masyarakat desa Simaroken, apabila hendak menanam padi, maka mereka akan mengadakan musyawarah kapan diadakan acara tolak bala dan hal ini sebagai wujud permohonan pada Allah, supaya tanaman mereka jauh dari jangkauan hama atau bala. (Nurhikmah et al., 2021)

Oleh karena itu, sesuai dengan paparan diatas terkait dengan tradisi tolak bala sebelum menanam padi yang dilakukan oleh masyarakat desa Simaroken Kabupaten Pasaman, maka penulis tertarik melakukan penelitian dan menggali secara mendalam kegiatan yang dilaksanakan oleh masyarakat setempat untuk mengusir bala dan penyakit yang ada dikampungnya terkhususnya bagi tanaman yang mereka tanam. Selain itu, penelitian ini bertujuan untuk mendapatkan secara rinci terkait prosesi tolak bala yang dilakukan oleh masyarakat setempat dan menggali nilai-nilai yang terkandung didalamnya, sehingga juga dapat menjadi sebuah khazanah baru dalam bidang keilmuan. Penelitian ini merupakan studi living Al-Qur'an yang bertujuan untuk menggali tradisi tolak bala yang dilakukan oleh masyarakat Desa Simaroken Kabupaten Pasaman.

Jika dirujuk dengan kajian yang relevan dengan penelitian ini, terdapat beberapa penelitian yang terkait, yaitu pertama, penelitian yang dilakukan oleh Syafrizal mahasiswa Fakultas Ilmu Sosial dan Ilmu Politik Universitas Teuku Umar Meulaboh dengan judul: Analisis Tradisi Tolak Bala dalam Tinjauan Sosiologi di Gampong Blang Baro Kecamatan Kuala Kabupaten Nagan Raya. Penelitian ini mengkaji terkait dengan tradisi tolak bala yang dilakukan oleh masyarakat Gampong Blang Baro dengan menggunakan tinjauan Sosiologi. (Syafrizal. 2021) Kedua, penelitian yang dilakukan oleh dosen UIN Suska Riau, yaitu Hasbullah dkk dengan judul Ritual Tolak Bala pada Masyarakat Melayu (Kajian pada Masyarakat Petalangan Kecamatan Pangkalan Kuras Kabupaten Palalawan). Hasil penelitian ini, bahwa masyarakat setempat melakukan tradisi tolak bala dengan tujuan untuk menghindarkan bala dan musibah pada kampung tersebut.(Hasbullah, Toyo, and Awang Pawi . 2017) Ketiga, penelitian yang dihasilkan oleh Azmi Fitrisia yang merupakan mahasiswa Fakultas Sosial 
Universitas Negeri Padang. Penelitian tersebut dengan judul Upacara "Tolak Bala" Refleksi Kearifan Lokal Masyarakat Nelayan Kenagarian Painan Kabupaten Pesisir Selatan Provinsi Sumatera Barat terhadap Laut.(Fitrisia 2014)

Dari beberapa penelitian yang telah dilakukan tersebut, maka persamaan dari penelitian yang penulis lakukan, yaitu samasama membahas terkait dengan tradisi tolak bala yang dilakukan oleh masyarakat. Namun perbedaan dari penelitian tersebut dengan penelitian yang penulis lakukan, yaitu penulis melakukan penelitian terkait dengan Tradisi tolak bala yang dilakukan oleh masyarakat yang bertempat pada Desa Simaroken Kabupaten Pasaman Provinsi Sumatera Barat. Selain itu, pada penelitian ini masyarakat Desa Simaroken Kabupaten Pasaman melakukan tradisi tersebut dengan tujuan untuk menghindarkan tanaman mereka dari bahaya dan penyakit, seperti hama. Dan tradisi tolak bala tersebut dilaksanakan sebelum menanam padi oleh para petani.

\section{METODE PENELITIAN}

Penelitian ini merupakan kajian living Al-Qur'an dengan menggunakan metode kualitatif field research (kajian lapangan) serta menggunakan pendekatan etnografi, (Saputra 2019b) karena tradisi tolak bala dalam prosesi tanam padi merupakan sebuah bentuk tradisi yang dilaksanakan oleh masyarakat secara kontiniu pada saat sebelum menanam padi. Teknik pengambilan data dalam penelitian ini, yaitu dengan melakukan observasi, wawancara dan dokumentasi. Wawancara yang dilakukan dalam mendapatkan data, maka penulis menghubungi tokoh masyarakat, petani yang melaksanakan tradisi, ulama dan masyarakat setempat. Lokasi penelitian ini adalah Desa Simaroken Kabupaten Pasaman Provinsi Sumatera Barat.

Setelah data didapatkan melalui para respomden, maka data tersebut akan dilakukan analisis serta disajikan dalam bentuk deskriptif terhadap tradisi tolak bala yang dilakukan oleh masyarakat Desa Simaroken Kabupaten Pasaman. Seluruh data yang disajikan pada penelitian ini merupakan hasil dari observasi dan wawancara langsung terhadap pelaksanaan kegiatan tradisi tolak bala.

Untuk lebih jelasnya, metode penelitian ini akan dijelaskan seperti alur yang tertera pada sekema yang tercantum di di bawah ini:

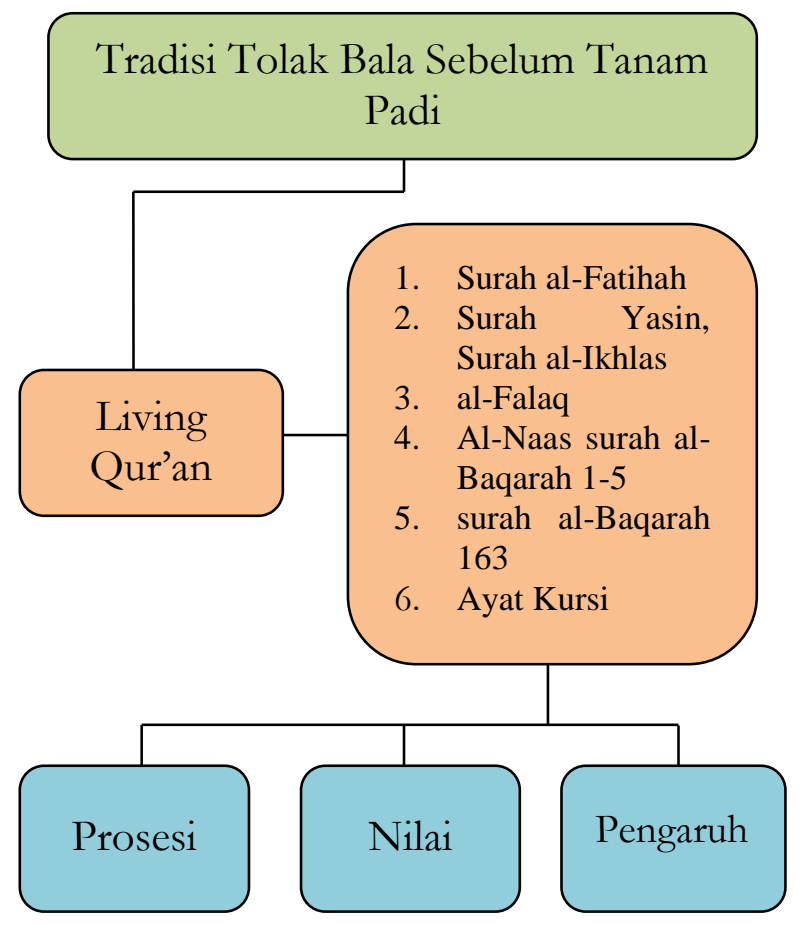

Skema 1: Alur Penelitian 


\section{HASIL DAN PEMBAHASAN}

Sebagaimana dijelaskan dalam pendahuluan, bahwa penelitian ini memaparkan secara rinci terkait dengan Potret sejarah tradisi Tolak Bala, prosesi pelaksanaan tolak bala dan nilai-nilai yang terkandung dalam pelaksanaan tradisi tersebut.

\section{Potret Sejarah Tradisi Tolak Bala}

Tradisi tolak bala sebelum proses tanam padi adalah kebiasaan yang dilaksanakan oleh masyarakat Desa Simaroken untuk menolak berbagai bentuk bala. Kebiasaan ini sudah merupakan suatu bentuk kewajiban bagi masyarakat sebagai bentuk rasa syukur serta niat mereka untuk menolak bala serta diiringi dengan minta ampun pada Allah atas segala dosa, karena dengan dosa semua bala berdatangan. (Simamaora, wawancara 2021).

Adapun sejarah latar belakang tolak bala ini adalah pada masa dahulu warga desa Simaroken ini ditimpa berbagai macam bala tanaman Padi, seperti Tikus, Attingano (Walang sengit) burung Pipit yang sangat merajalela sehingga petani tidak kuat dengan hal tersebut, sehingga warga masyarakat musyawarah untuk mencari solusi dari masalah tersebut, hasil dari musyawarah tersebut bahwa masyarakat akan mengadakan tolak bala,jikabala yang mengancam tanaman warga tersebut berkurang dan pendapatan hasil padi meningkat. Adapun alasan mengapa tradisi ini dinamakan tradisi tolak bala sebelumb proses tanam padi adalah, karena menanam padi sudah warga lakukan dari awal mereka lahir sampai saat sekarang ini, dibandingkan mereka mengenal tanaman yang lain seperti jagung. Menanam jagung merupakan barubaru ini mereka lakukan jika dibanding tanaman padi. (Zulfadli et al. 2021)

Dalam pengungkapan sejarah yang lebih jelas mengenai tahun berapa tradisi tolak bala ini di adakan pertama kali, penulis tidak menemukannya.Secara umum masyarakat melakukan tradisi ini mempunyai berbagai macam tujuan, diantaranya sebagai peredam masalah bagi masyarakat, sebagai obat kalau ada yang sedang sakit, pemersatu masyarakat, dan lain sebagainya, secara khusus untuk menolak bala yang yang datang pada tanaman padi.(Roslaini, wawancara 2021)

Dari penjelasan di atas, bahwa tradisi tolak bala ini dilakukan dengan membaca Al-Qur'an, berdzikir, makan bersama. Dengan tujuan untuk meminta ampun pada Allah, menolak bala, memperbaiki hasil panen padi, menyembuhkan penyakit, meredam masalah, mempererat persaudaraan masyarakat.

Adapun hadis Rasulullah yang menyebutkan tentang keutamaan keutamaan berkumpul (berjamaah) untuk membaca AlQur'an al-Karim, mempelajari dan mengkajinya, terutama jika hal tersebut diadakan di dalam masjid yang menjadi pengikat hati orang-orang yang beriman; adalah hadis yang diriwayatkan dari Abu Hurairah RA, ia berkata: "Telah bersabda Rasulullah SAW.

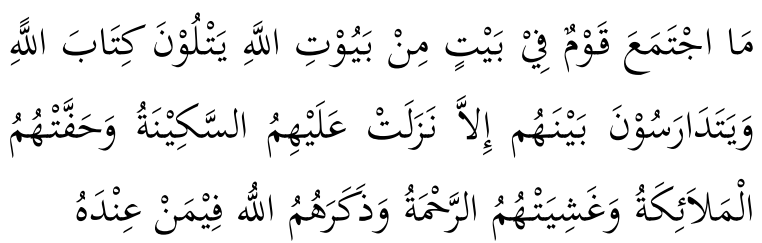


Artinya: "Tidaklah berkumpul suatu kaum di sebuah rumah Allah (masjid),mereka membaca Kitab Allah dan mempelajarinya di antara mereka,terkecuali akan turun ketentraman kepada mereka, hati-hati mereka dipenuhi rahmat, diliputii oleh para malaikat dan Allah menyebut mereka di hadapan makhluk-Nya. (H.R.Bukhari)

Hadis ini adalah berita gembira yang disampaikan oleh Nabi SAW kepada orangorang yang berkumpul untuk membaca dan mempelajari Al-Qur'an.Rasulullah SAW mengajak dan memotivasisahabatnya (umatnya) untuk mempelajari Al-Qur'an, karena hal tersebut adalah kunci untuk kekuatan dan kemuliaan.Juga terdapat balasan yang besar dari Allah untuk para pambaca Al-Qur'an,baik itu mereka berkumpul di masjid atau di tempat-tempat yang lainnya, seperti sekolah atau rumah.

Siapa yang menghadiri sebuah majlis (Al-Qur'an), maka ia akan mendapatkan empat macam kebaikan yang besar, yaitu: pertama, Turun ketenangan menyelimuti hati mereka. Kedua, hati mereka diselubngi oleh Rahmat. Ketiga, mereka dinaungi oleh para malaikat Allah. Keempat, Allah menyebutnya mereka dihadapan makhluknya.

Maka dapat simpulkan bahwa, sejarah yang melatarbelakangi terjadinya proses tradisi tolak bala di desa Simaroken adalah keresahan warga terhadap bala tanaman Padi yang mengancam panen, sehingga masyarakat berikhtiar untuk melakukan tolak bala dan berniat apabila tanaman padi berhasil, maka masyarakat akan melakukannya kembali dan akhirnya tradisi tolak bala ini sudah menjadi sesuatu kewajiban bagi masyarakat.

\section{Prosesi Tradisi Tolak Bala Sebelum Tanam Padi}

Selanjutnya, mengenai tempat pelaksanaan tradisi tolak bala, masyarakat selalu melakukannya di dalam Mesjid sebagai tempat yang lebih afdhol diantaranya untuk tempat bermunajat pada Allah.(Simamora, wawancara 2021) Mengenai waktu tradisi tolak bala ini, masyarakat selalu melaksanakannya pada hari Kamis malam, atau malam Jumat setelah sholat Isya, karena diantara hari yang afdhol untuk berdoa pad Allah adalah hari Jumat.

Berdoa adalah resepsi permintaan seorang hamba pada Allah supaya Allah mengabulkannya, oleh karena itu perlu bagi seorang mukmin untuk memperhatikan waktu-waktu khusus yang mustajab sesuai anjuran Rasulullah SAW. Walaupun kita tahu bahwa Allah berkuasa mutlak untuk mengabulkan doa hambanya kapan dan dimanapun itu. Sesuai dengan perintah Rasulullah SAW bahwa ada waktu dimana doa seseorang dikabulkan oleh Allah yaitu pada hari Jumat. Oleh karena itu, hendaklah seorang mukmin memperbanyak permohonan pada hari itu. Sesuai hadis Rasulullah SAW:

Dari Abu Hurairah RA., bahwa Nabi SAW. bersabda :

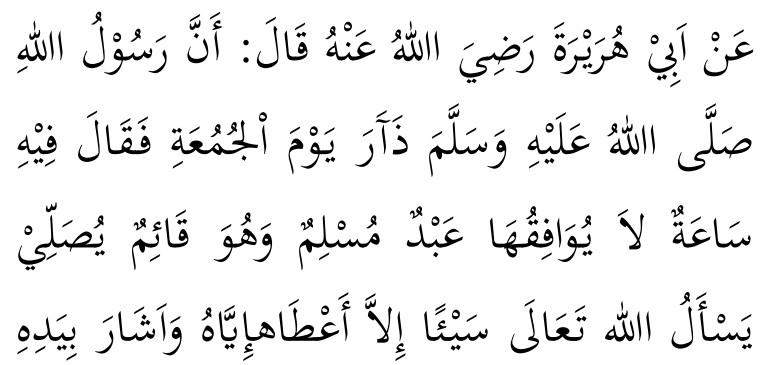




$$
\text { يُعَلِلِهُها رواه البخارى }
$$

Artinya: "Sesungguhnya Rasululllah Saw. menuturkan tentang hari jum'at.Beliau bersabda: "Didalamnya ada suatu saat,yang tidak seorang muslim sedang berdiri shalat seraya memohon kepada Allah Ta'ala akan sesuatu bertepatan dengan saat itu,melainkan Allah pasti akan memberinya, dan beliau mengisyaratkan dengan jari-jari beliau karenamensedikitkannya". (HR.Bukhari) (Al Bukhari 1993)

Pelaksanaan acara ini dilakukan dua kali dalam setahun, acara ini diadakan setelah masyarakat hendak menanam padi, sebelum acara tradisi ini, akan ada informasi dari ketua kelompok tani yaitu Uda (paman) Remon Ritonga, isi dari hasil pengumuman tersebut Uda tersebut akan mengumumkan hari dan tanggal yang tepat dilaksanakan acara tradisi tolak bala tersebut, dan dalam pemberitahuan tersebut akan diumumkan padi apa yang akan ditanam, serta tidak boleh berbeda jenis padinya.(Ritonga 2021) Adapun tahapan-tahapan dalam tradisi pembacan surah Yasin dan surah pilihan sebelum proses tanam padi adalah sebagai berikut:

Pertama, Tahap persiapan. Adapun pada tahapan awal ini, semua warga desa Simaroken diwajibkan membawa lomang (lamang) yang sudah masak sebanyak satu bambu perorang, untuk dimakan bersama di masjid setelah acara selesai. Lamang dikenal sebagai makanan masyarakat Sumatera Barat, yang terbuat dari beras sipulut (ketan) yang diisi ke dalam dengan bambu (talang, buluh).Kalau dari segi jenis lamang ini, ada beberapa jenis, proses pembuatannya sama yang membedakannya hanya bahannya saja. Ada beberapa jenis lamang diantaranya, lamang pisang, lamang ubi, lamang durian, lamang jagung. (Resfirul. 2017) nama lamang yang terdapat dalam kehidupam masyarakat Sumatera Barat, yaitu Lamang Sipuluik, Lamang Pisang, Lamang Kuning dan Lamang Ubi Di antara lamang yang sering dibuat oleh masyarakat adalah lamang dari sipulut (ketan) atau biasa disebut dengan lamang sipuluik. Dari kebiasaan masyarakat desa Simaroken, lamang sipuluiklah yang biasa mereka hidangkan ketika mengadakan tradisi tolak bala. Kedua, Tahap Pelaksanaan. Dalam pelaksanaan tradisi tolak bala sebelum menanam padi, maka masyarakat harus mengikuti aturan yang berlaku ditempat tersebut, yaitu:

1) Diharuskan berangkat dari rumah dalam keadaan suci (berwudhu) dan bersih badan dan pakaian.

2) Para jamaah sebanyak 40 orang duduk melingkar dan merapat, serta lutut bersentuhan, selain dari yang 40 orang tersebut duduk seperti biasa sambil bersandar di dinding masjid.

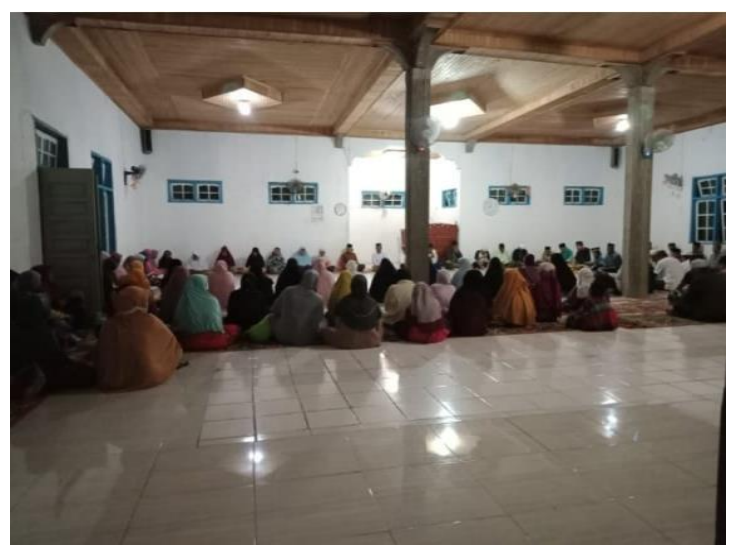

Gambar 1: Warga Duduk Melingkar dalam Acara Tolak Bala 
3) Jamaah yang 40 orang tersebut dipilih oleh alim 'Ulama, yaitu orang yang lebih fasih bacaan Al-Qur'annya.Adapun kenapa duduk melingkar supaya lebih khusu' dalam bermunajat pada Allah, karena siapa yang yang bermunajat pada Allah sebanyak 40 orang, pasti salah satu diantara mereka ada yang diijabah doanya.

4) Setelah warga duduk rapi dan tenang di dalam masjid, 'Alim 'Ulama menunjuk siapa yang akan membawa acara, membaca tahlil, membaca surah pilihan, dan siapa yang membaca doa.

5) Warga mendengarkan dan mengikuti rangkaian acara tradisi tolak bala sebelum menanam, yaitu: Membaca Istighfar (minta ampun kepada Allah darisegala dosa baik jasad maupun hati), Membaca surah al-Fatihah, membaca surah Yasin, Membaca surah al-Ikhlas, al-Falaq dan Al-Naas sebanyak tiga kali, Membaca surah al-Baqarah ayat 1-5, Membaca surah al-Baqarah ayat 163, Membaca surah al-Baqarah ayat 255 (ayat Kursi), Membaca surah al-Baqarah ayat 284-286, membaca Tahlil dan Terakhir dilanjutkan dengan berdoa sama-sama yang dipimpin oleh 'Alim 'Ulama.

Ketiga, tahap penutupan setelah selesai berdoa bersama-sama sebagai penutup dan permohonan doa kepada Allah, supaya bala yang akan membahayakan tanaman padi menjauh, maka diakhir dari acara ini ialah semua warga masyarakat desa Simaroken secara bersama-sama menikmati masakan Lamang (lomang) yang sudah disiapkan sebelumnya. Acara makan lamang inilah bentuk rasa syukur warga desa Simaroken pada Allah dan sebagai salah satu jenis tanaman mereka tanam di sawah.

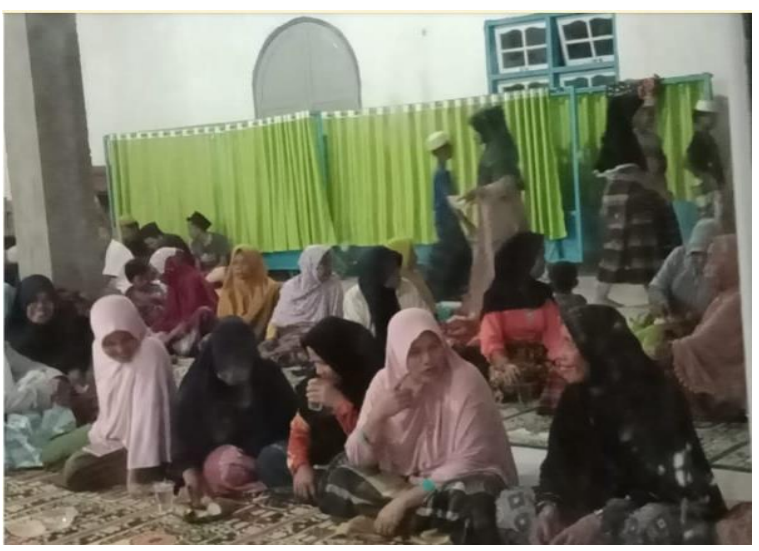

Gambar 2: Warga Menyantap Lamang sebagai sajian pada prosesi tolak bala

Nilai yang Terkandung pada Prosesi Tradisi Tolak Bala Sebelum Menanam Padi

Tradisi Tolak Bala sebelum Tanam Padi pada masyarakat Desa Simaroken Kabupaten Pasaman Provinsi Sumatera Barat merupakan kegiatan rutin dilaksanakan oleh masyarakat setempat, karena selain dalam bentuk kebiasaan masyarakat sekitar, kegiatan tersebut juga memiliki banyak nilai-nilai yang terkandung didalamnya, diantaranya:

a. Sebagai Doa

Allah SWT akan membalas bagi hambanya yang berdoa pada-Nya, ada beberapa manfaat dari berdoa, diantaranya sebagai berikut:

1) Doa merupakan perbuatan yang diperintahkan oleh Allah SWT, siapa saja yang berdoa maka ia termasuk bagian yang taat pada Allah SWT, dan siapa terkabul doanya akan mendapat dua kebaikan, pahala dan terkabulnya doa, sedangkan orang yang belum 
terkabul ia mendapatkan satu kebaikan yakni nilai ibadah dari doanya.

2) Orang yang berdoa akan mendapatkan berbagai kebaikan dari ibadah doanya, menjadi orang yang rendah hati, dan tidak sebaliknya, bila belum terkabul maka ia tidak berputus asa dari rahmat Allah.

3) Orang yang bedoa akan akan selalu positif thingking terhadap janji Allah dan menyadari bahwa semua tergantung pada kebijaksanaan Allah, cepat atau lambat Allah kabulkan. (wijayakusuma. 2017)

Dalam pelaksanaan tradisi ini masyarkat melakukan ini atas dasar doa terhadap Allah supaya semua bentuk cobaan dijauhkan oleh Allah dari semua warga, sebagaimana firman Allah.

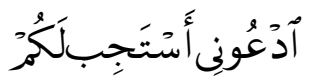

Artinya: "Berdoalah kepada-Ku, niscaya akanKuperkenankan bagimu.(Q.S Ghofir: 60)

Dalam penjelasan Oppung Manginar tantang ayat tersebut bahwa,

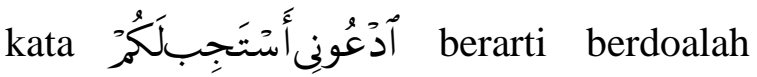
kamu kepadaku, kamu disini tidak berarti satu orang atau dua orang akan tetapi berarti banyak (meminta secara berjamaah).

Dan juga firman Allah pada sura lainnya:

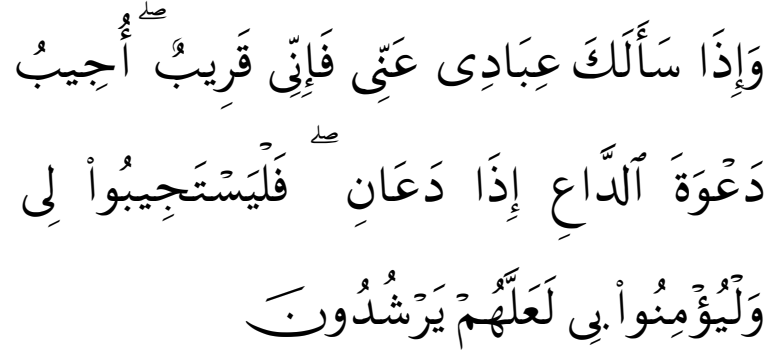

Artinya: dan apabila hamba-hamba-Ku bertanya kepadamu tentang Aku, Maka (jawablah), bahwasanya aku adalah dekat. aku mengabulkan permohonan orang yang berdoa apabila ia memohon kepada-Ku, Maka hendaklah mereka itu memenuhi (segala perintah-Ku) dan hendaklah mereka beriman kepada-Ku, agar mereka selalu berada dalam kebenaran. (Q.S. al-Baqarah: 186)

b. Sebagai penanaman niat

Dalam kebiasaan masyarakat desa Simaroken melakukan tradisi tolak bala ini, ketika proses pelaksanaan tolak bala sedang berlangsung, waktu itulah warga menanamkan niat pada Allah, jika penanaman padi mendapatkan hasil yang baik, maka masyarakat akan mengadakan tolak bala. (Salimah, wawancara 2021)

c. Menambah berkah

Semoga dengan pembacaan AlQur'an yang dibaca dan niat yang ikhlas karena AllahTa'ala, akan mendapatkan keberkahan dalam berusaha di dunia dan mendapatkan kebahagiaan di akhirat.

d. Sebagai Penolak Bala

Dalam tradisi ini, warga masyarakat desa Simaroken melakukan tradisi tolak bala ini dengan makna untuk menolak bala yang ada di desa Simaroken. Bala secara umum, bukan hanya untuk tanaman yang berupa hama saja, akan tetapi, bala itu banyak yang diantaranya penyakit yang akan mengindap ditubuh warga, perpecahan yang akan terjadi diantara sesama warga desa Simaroken, secara umum segala bentuk negatif yang akan merugikan bagi masyarakat desa Simaroken.(Manginar, wawancara 2021)

e. Sebagai penolak penyakit 
Hama dan penyakit merupakan sesuatu hama yang dapat merusak hasil pertanian masyarakat setempat, maka dengan kegiatan tolak bala tersebut yang dilakukan oleh masyarakat sebelum menanam padi akan merupakan bentuk ikhtiar dari masyarakat setempat dalam membasmi hama tersebut.

f. Untuk mempererat tali persaudaraan

Melalui kegiatan tolak bala yang dilakukan oleh masyarakat Desa simaroken, maka banyak nilai positif yang didapatkan, diantaranya mewujudkan tali silaturrahmi antar masyarakat dengan melakukan setiap pekerjaan secara bersama-sama (gontong royong).

\section{Pengaruh Tradisi Tolak Bala Sebelum Menanam Padi}

1. Bala berkurang

Dari tradisi tolak bala yang masyarakat lakukan, warga merasakan manfaat yang sangat banyak sekali, diantaranya yaitu, segala macam bala tanaman berkurang, baik itu bala tikus, burung pemakan padi, wereng, walang sengit, hama putih, ulat, dll. Jika dibandingkan dengan desa sekitar, jauh lebih aman tanaman desa Simaroken, desa ini tidak ada menjaga tanaman dari hama, sedangkan desa yang lain, dalam hal penjagaan padi perlu penjagaan ekstra diantaranya menciptakan pelindung bagi tanaman padi yang berupa plastik dari serangan tikus, serta mengambil bekasbekas makanan padi dari sawah dan membuangnya ke tempat lain.Selanjutnya desa yang lain menjaga tanaman dari makanan burung (istilah desa Simaroken Mamuro) yang sering warga jaga pada waktu pagi dan sore, dijaga waktu pagi karena burung mau makan pagi (sarapan) dan dijaga pada waktu sore karena burung mau makan malam, dalam waktu tersebut warga sangat ekstra dalam menjaga tanaman padi. (Roslaini, wawancara 2021)

Dalam kurun waktu kurang lebih satu tahun (dua kali panen) masyarakat desa Simaroken mencoba tidak melakukan tradisi tolak bala ini.Akibatnya, masyarakat merasakan kembali keresahan terhadap banyaknya hama yang datang pada tanaman padi, sehingga warga memutuskan untuk tetap melaksanakan tradisi ini sampai saat sekarang ini. (Simamora, wawancara 2021)

Peningkatan panen yang dirasakan oleh warga desa Simaroken, bukan sematamata karena turun serentak menanam padi yang mereka lakukan, melainkan karena keberkahan yang Allah berikan bagi mereka melalui usaha dan doa, sekaligus ikhtiar tolak bala yang mereka lakukan. Itu terbukti dari pernyataan dari dari ketua kelompok tani yaitu Uda (paman) Remon Ritonga, dan Oppung Manginar ('alim ulama).Dalam pernyataan mereka bahwa, dampak positif dari tradisi tolak bala ini sangatlah banyak, salah satunya ialah meningkatnya pendapatan para warga ketika padi dipanen, justru karena itulah tradisi ini masih tetap dipertahankan oleh warga desa Simaroken.

\section{Panen meningkat}

Dari hasil pendapatan yang warga rasakan setelah melakukan tradisi tolak bala, warga merasakan kepuasan dibanding dari daerah lain, minimal warga mendapatkan 40 kaleng dalam satu 
lungguk, berbeda dengan daerah lain yang sering mengalami kemerosotan pendapatan bahkan sering merasakan gagal panen.(Roslaini, wawancara 2021)

3. Meningkatnya ekonomi masyarakat

Salah satu manfaat yang dirasakan oleh warga desa Simaoken setelah melakukan tradisi tolak bala adalah peningkatan ekonomi yang pesat, walaupun pekerjaan warga hanya sekedar sebagai buruh kerja, akan tetapi pembangunan dan ekonomi sebegitu cepat meningkat dibanding dengan desa lain. Salah satu pengalaman dari mereka bercerita bahwa, banyak diantara penduduk desa lain yang berkunjung dari desa mereka tinggal, sambil melihat perubahan dari tatanan pembangunan, dan mereka merasa takjub dan bertanya, apa pekerjaan kalian sehingga begitu cepat pembangunan disini? (Manginar, wawancara 2021)

\section{Masalah berkurang}

Tradisi tolak bala juga berperan sebagai peredam dari berbagai macam masalah, melalui tradisi ini ukhuwah atau rasa persaudaraan satu kampung begitu erat, serta menyatukan kembali kerenggangan yang pernah terjadi, dan saling maaf memaafkan satu sama lain layaknya dihari besar Islam yaitu hari Raya Idul Fitri dan hari Raya Idul Adha.

\section{Persatuan tambah erat}

Tradisi tolak bala ini sebagai penyokong persatuan masyarakat desa Simaroken, dari proses pelaksanaannya terlihat jelas bahwa, seluruh masyarakat harus ikut serta dalam mengikuti acara tersebut, mulai dari awal penetapan hari, penetapan jenis padi yang akan ditanam, sampai ahir dari acara tersebut semua masyarakat harus sama-sama makan Lomang sebagi hasil tanaman yang sudah dipanen sebelumnya.

6. Kader generasi maju

Tradisi tolak bala menjadi salah satu bimbingan pada anak-anak desa Simaroken, berbeda dengan desa yang lain yang melahirkan anak-anak yang bisa disebut pintar tapi tidak sampai menjadi figur masyarakat atau menjadi peminpin besar, berbeda halnya dengan desa ini, yang melahirkan generasi yang lebih terlatih dalam kegiatan-kegiatan Islam, karakter-karakternya terdidik dengan baik dan tangguh, sehingga terlahir dari ankaanak mereka yang menjadi peminpinpeminpin yang handal dan tangguh, salah satu dinatara mereka adalah Alm Kumpul Ritonga yang terpilih sebagai DPRD Kabupaten Pasaman selama satu priode pada tahun 2019, dan pada tahun ini almarhum menutup usianya. Yang kedua Sabar AS terpilihnya sebagai DPRD Provinsi Sumatera Barat selama tiga priode dari tahun 2009 sampai 2020, dan sekarang menjabat sebagai Wakil Bupati Pasaman Timur.(Yanti, wawancara 2021)

\section{SIMPULAN}

Tradisi tolak bala yang dilaksanakan oleh masyarakat Simaroken Kabupaten Pasaman merupakan salah satu bentuk jegiatan yang dilakukan secara kontoniu pada saat sebelum menanam padi oleh masyarakat setempat. Kegiatan ini selalu diwariskan kepada generasi selanjutnya, agar tradisi tersebut tidak hilang dengan adanya perkembangan zaman. Pelaksanaan 
tradisi tolak bala ini dilakukan secara bersama-sama oleh seluruh masyarakat setempat dan menyiapkan bahan-bahan tertentu, seperti makanan yang akan dihidangkan dan lamang. Kegiatan tolak bala sebelum menanam padi ini dipimpin oleh seorang ulama yang telah dipercaya oleh masyarakat setempat dan juga memimpin pelaksanaan acara tolak bala serta diikuti oleh masyarakat setempat.

\section{DAFTAR PUSTAKA}

Andana, Halim. 2020. "The Variation Of Language In the Qur'an Minang Translation; Sociolinguistics Review." Jurnal At-Tibyan: Jurnal Ilmu Alqur'an dan Tafsir 5(2):281-306. doi: 10.32505/at-tibyan.v5i2.1875.

Aisyah, S. N. (2016). Persepsi Masyarakat Terhadap Tradisi Ritual Tolak Bala Bulan Safar Pada Desa Sidomulyo Kec. Tanah Putih Kab. Rohil Menurut Perspektif Hukum Islam. Universitas Islam Negeri Sultan Syarif Kasim Riau. http://repository.uinsuska.ac.id/2778/

Aziz, Erwati. 2010. Musykil AlQur'an, Yogyakarta, Intan Cendikia.

Eviyanti, E. (2018). Bhangka Mbule-Mbule: Tradisi Tolak Bala pada Masyarakat di Kelurahan Mandati Kecamatan Wangi-Wangi Selatan Kabupaten WakatobI. Etnoreflika: Jurnal Sosial Dan Budaya, 7(3), 202-211. https://doi.org/10.33772/etnoreflika.v $7 \mathrm{i} 3.552$

Fitrisia, Azmi. 2014. "Nelayan Kenagarian Painan Kabupaten Pesisir Selatan Propinsi Sumatera Barat Terhadap Laut." 8.

Hasbullah, H., Toyo, T., \& Pawi, A. A. A. (2017). Ritual Tolak Bala Pada Masyarakat Melayu (Kajian Pada Masyarakat Petalangan Kecamatan
Pangkalan Kuras Kabupaten Pelalawan). Jurnal Ushuluddin, 25(1), 83-100.

http://dx.doi.org/10.24014/jush.v25i1. 2742

Hidayat, Rahmat. 2019. "Agama Dalam Persfektif Al-Qur'an.” Jurnal Ulunnuha 8(1):127-41. doi: 10.15548/ju.v8i1.296.

Gusnanda. 2020. "Mambadakan Paja: Pergumulan Islam dan Tradisi Lokal di Nagari Kamang Mudiak Kabupaten Agam Sumatera Barat.” 06:13.

Nurhikmah, N., Said, N. M., Malik, A., \& Syam, M. T. (2021). Adaptasi Dakwah dalam Tradisi Tolak Bala Masyarakat Kota Parepare. Jurnal Dakwah Risalah, 32(1), 20-39. http://dx.doi.org/10.24014/jdr.v32i1.1 2857

Ramanda, Deski, Edriagus Saputra, and Dian Puspita Sari. 2018. "Pengaruh Qirā'āt Terhadap Penafsiran.” 16.

Refisrul. 2017. Lamangdan Tradisi Malamangpada Masyaraat Minangkabau. Jurnal Penelitian Sejarah dan Budaya, Vol. 3 No. 2.

Ritonga, Remon. Wawancara langsung dengan ketua kelompok tani Desa Simaroken, 24 Januari 2021 jam 16:10

Roslaini, Nantulang. Wawancara langsung dengan ketua P3K Desa Simaroken, 24 Januari 2021 Jam 15:31

Salimah, Nantulang. wawancara langsung dengan masyarakat Desa Simaroken, 24 Januari 2021 Jam 07:10

Saputra, Edriagus. 2019a. "Tradisi Menghiasi Hewan Kurban pada Masyarakat Kenagarian Bawan." Fokus Jurnal Kajian Keislaman dan Kemasyarakatan 4(1):1. doi: 10.29240/jf.v4i1.763.

Saputra, Edriagus. 2019b. "Tradisi Menghiasi Hewan Kurban pada 
Masyarakat Kenagarian Bawan." Fokus Jurnal Kajian Keislaman dan Kemasyarakatan 4(1):1. doi: 10.29240/jf.v4i1.763.

Saputra, Edriagus, and Azamel Fata. 2021. "The Method of Understanding the Hadith of Ibn Rajab Al-Hanbali in the Book of Jami 'al-'Ulûm wa al- Hikam fî Syarh Khamsîn Hadîtsân min Jawâmi' al-Kalim.” 16.

Shihab,Umar. 2005. Kontekstualitas AlQur'an, Jakarta, Penamadani.

Simamora, Tulang Aziz. wawancara langsung dengan tokoh adat Desa Simaroken, 24 Januari 2021 Jam 07:10

Wijayakusuma, Hembing. 1997. Hikmah Shalat Untuk Pengobatan dan Kesehatan, Jakarta;Pustaka Kartini.

Yanti, Pitra. Wawancara langsung dengan masyarakat, Pasaman 29 Januari 2021 Jam 07:31

Zulfadli, Muhammad, Luqmanul Hakim, Novizal Wendry, and Edriagus Saputra. 2021. "Akulturasi Islam dan Budaya Lokal dalam Tradisi Mangaji Kamatian Pada Masyarakat Lareh Nan Panjang Kabupaten Padang Pariaman." Jurnal SMART (Studi Masyarakat, Religi, dan Tradisi) 7(01):103-14. doi: 10.18784/smart.v7i01.1257. 